\title{
Rumen degradation and intestinal digestibility of amino acids in different roughages estimated by nylon bag techniques
}

\section{Halina Skórko-Sajko', Torben Hvelplund and Martin R. Weisbjerg}

\author{
National Institute of Animal Science, \\ Department of Research in Cattle and Sheep, \\ Research Centre Foulum, \\ P.O. Box 39, DK-8830 Tjele, Denmark
}

(Received 4 January 1994; accepted 21 February 1994)

\begin{abstract}
Rumen degradability of protein and amino acids were estimated using the nylon bag technique in four different roughages: cocksfoot, vetch whole crop, clover grass, and lucerne pellets after incubation in the rumen for 4 or $16 \mathrm{~h}$, respectively. Intestinal digestibility of protein and amino acids were estimated by the mobile nylon bag technique in the intact protein and in residues pre-incubated in the rumen for $16 \mathrm{~h}$.

Degradability of total amino acid nitrogen followed the samc trend as for nitrogen, whereas notable differences were observed for individual amino acids, especially for methionine. Intestinal digestibility of intact feed protein varied between 0.820 and 0.887 for nitrogen, and between 0.869 and 0.931 for total amino acid nitrogen. Among the individual amino acids only cystine differed markedly from the mean value for total amino acids. Intestinal digestibility of $16 \mathrm{~h}$ rumen pre-incubated protein was much lower than for the intact protein and varied between 0.444 and 0.748 for nitrogen, and between 0.559 and 0.844 for total amino acid nitrogen. In all samples tested a higher digestibility was observed for total amino acid nitrogen compared to total nitrogen.
\end{abstract}

KEY WORDS: ruminants, amino acid profile, degradability, protein

\section{INTRODUCTION}

In the Nordic AAT-PBV protein evaluation system for ruminants (Madsen, 1985 ) the protein value of a feed is expresed as the AAT value (amino acids truly absorbed from the small intestine). Two important parameters used to estimate the AAT value are degradability of the protein in the rumen and intestinal digestibility of the undegraded protein.

Nylon bag methods have been used to predict both of these parameters. The nylon bag method used to measure protein degradation in the rumen has been

1 Present address: Institute of Animal Nutrition and Feed Management, Academy of Agriculture and Technology, 10-718 Olsztyn-Kortowo, Poland 
described by Ørskov and McDonald (1979), Kristensen et al. (1982), and recently tested by Madsen and Hvelplund (1994). The mobile nylon bag technique, which is a relatively simple method for predicting the true intestinal digestibility of undegraded dietary protein, has been tested by Hvelplund (1985), De Boer et al. (1987), Hvelplund et al. (1992), and Jarosz et al. (1994).

Protein degradation in the rumen influences the ratio between amino acid nitrogen (AAN) and total $\mathrm{N}$ in the residue after incubation compared to the ratio in the feed protein. Results presented by Rooke et al. (1984) and Hvelplund (1987) indicate a decrease in the ratio between AAN and total $\mathrm{N}$ for different roughages after pre-incubation in the rumen.

A significant relationship between the protein degradability in the rumen and the true digestibility of undegraded protein has been obtained by Hvelplund et al. (1992). An increased degradability of protein in the rumen results in a reduced digestibility of the rumen undegraded protein. A low intestinal digestibility of the undegraded feed protein compared to the original feed protein is observed if the feedstuffs contain a significant portion of protein, which is both totally indigestible in the intestine and undegradable in the rumen (Hvelplund et al., 1992).

The present study was undertaken to determine protein and amino acid degradability of four different roughages after 4 and $16 \mathrm{~h}$ incubation in the rumen, respectively, and to test the protein and amino acid digestibility in the small intestine of original and rumen undegraded protein.

\section{MATERIAL AND METHODS}

The experiment was carried out on two dairy cows equipped with a rumen cannula and a duodenal cannula. The cows were fed a standard diet at maintenance level consisting of grass hay and concentrate ( $1 / 3$ concentrate and $2 / 3$ hay on feed basis).

\section{Rumen degradation}

Cocksfoot, vetch whole crop, clover grass, and lucerne pellets were incubated in the rumen using the nylon bag technique. The nylon bags, with a pore size of $36 \times 36 \mu \mathrm{m}$, were placed in the rumen of each at 8 am and incubated for 4 or $16 \mathrm{~h}$, respectively. Ten bags, each containing $1 \mathrm{~g}$, were used for $4 \mathrm{~h}$ incubation, and 20 bags, each containing $1.5 \mathrm{~g}$, were used for $16 \mathrm{~h}$ incubation. All feedstuffs were incubated in the rumen according to the procedure described by Kristensen et al. (1982). After incubation the bags were washed in a domestic washing machine, treated in a stomacher to remove microbial contamination, and freeze dried before further analysis. 


\section{Intestinal digestibility}

The true intestinal digestibility of the different samples were estimated by the mobile nylon bag technique (Hvelplund et al., 1992). Undegraded dietary protein was prepared as described above. Each intestinal bag (pore size $9 \mathrm{x} 9 \mu \mathrm{m}$; dimension $6 \times 6 \mathrm{~cm}$ ) was weighted with approx. $0.5 \mathrm{~g}$ freeze dried residues or original protein, and the bags were heat-sealed.

The samples were pre-incubated in a pepsin- $\mathrm{HCl}$ solution $(100 \mathrm{mg}$ pepsin per 1 of $0.004 \mathrm{M} \mathrm{HCl}$ solution, $\mathrm{pH} 2.4$ ) for $2 \mathrm{~h}$ at $39^{\circ} \mathrm{C}$ and introduced into the intestines of the cows through the duodenal cannula ( 12 mobile bags/cow/day). The bags were recovered from the faeces, washed, and the residues were freeze dried before further analysis.

\section{Chemical analysis and calculations}

The feedstuffs and residues were analyzed for dry matter (DM) and nitrogen (N) according to conventional methods (A.O.A.C., 1990). Amino acids were determined by the method described by Mason et al. (1980).

Degradability and true intestinal digestibility of protein and amino acids were calculated as the disappearance from the bags after rumen incubation or passage through the intestine, respectively.

\section{RESULTS}

The nitrogen content and amino acid composition of the four tested feedstuffs are given in Table 1. The concentration of total AAN was higher for clover grass and lucerne pellets (approx. $66.5 \mathrm{~g} / 100 \mathrm{~g}$ of $\mathrm{N}$ ) compared to cocksfoot and vetch whole crop (approx. $61 \mathrm{~g} / 100 \mathrm{~g}$ of $\mathrm{N}$ ). Differences in the concentration of individual amino acids among the different feeds were also found as shown in Table 1.

The degradability of protein and amino acids in the four roughages, after 4 and $16 \mathrm{~h}$ incubation in the rumen, are shown in Table 2. Ruminal $\mathrm{N}$ and AAN disappearance increased with rumen incubation time. Degradability of $\mathrm{N}$ after 4 and $16 \mathrm{~h}$ incubation in the rumen were 0.486 and 0.699 for cocksfoot, 0.729 and 0.864 for vetch whole crop, 0.615 and 0.786 for clover grass, and 0.517 and 0.630 for lucerne pellets, respectively. Degradability of total AAN followed the same trend as nitrogen and only small differences were observed, whereas there were notable differences among individual amino acids, and methionine seemed to be the amino acid most resistant to degradation as the degradability of this amino acid in all cases was lower than for nitrogen. The degradability of $\mathrm{N}$ and total AAN after 4 or $16 \mathrm{~h}$ incubation in the rumen for cocksfoot and lucerne pellets 
TABLE 1

Nitrogen content and amino acid composition of the feedstuffs (tryptophan was not estimated)

\begin{tabular}{lrcrc}
\hline & Cocksfoot & $\begin{array}{c}\text { Vetch whole } \\
\text { crop }\end{array}$ & $\begin{array}{c}\text { Clover grass } \\
\text { pellets }\end{array}$ \\
\hline Nitrogen content (\% in DM) & 2.58 & 3.65 & 2.09 & 3.80 \\
Total amino acid N (\% of total N) & 61.65 & 60.41 & 66.20 & 66.86 \\
Amino acid composition (g AAN/100 g N): & & & & \\
Alanine & 5.59 & 4.58 & 5.29 & 4.86 \\
Arginine & 8.64 & 7.61 & 9.32 & 8.54 \\
Aspartic acid & 5.11 & 8.53 & 6.47 & 7.78 \\
Cystine & 0.76 & 0.69 & 0.63 & 0.76 \\
Glutamic acid & 5.45 & 4.52 & 5.48 & 5.21 \\
Glycine & 5.25 & 4.85 & 5.42 & 5.16 \\
Histidine & 2.65 & 3.13 & 3.14 & 3.64 \\
Isoleucine & 2.55 & 2.35 & 2.73 & 2.69 \\
Leucine & 4.45 & 3.72 & 4.66 & 4.51 \\
Lysine & 4.26 & 4.67 & 4.52 & 5.49 \\
Methionine & 0.78 & 0.60 & 0.79 & 0.78 \\
Phenylalanine & 2.56 & 2.09 & 2.55 & 2.43 \\
Proline & 3.08 & 2.52 & 3.68 & 3.18 \\
Serine & 3.10 & 3.36 & 3.39 & 3.51 \\
Threonine & 2.77 & 2.40 & 2.89 & 2.86 \\
Tyrosine* & 1.03 & 1.56 & 1.40 & 1.73 \\
Valine & 3.62 & 3.23 & 3.84 & 3.73 \\
\hline
\end{tabular}

* Tyrosine is increased with $15 \%$ to adjust for oxidation losses. This gives an approximate estimation of this amino acid which should only be used for summation

was lower compared to the degradability found for vetch whole crop and clover grass.

The proportion of total AAN in orginal and undegraded dietary protein after 4 and $16 \mathrm{~h}$ of rumen incubation is shown in Table 3 . The proportion of amino acids in the undegraded protein after $4 \mathrm{~h}$ of incubation had only changed to a small extent compared to the original protein. After $16 \mathrm{~h}$ of incubation a decrease was observed, except for cocksfoot for which incubation in the rumen increased the proportion of amino acids.

Results on intestinal digestibility obtained by the mobile nylon bag technique on original protein in the different feedstuffs and rumen undegraded protein after $16 \mathrm{~h}$ pre-incubation in the rumen are given in Table 4 . The intestinal digestibility in the original protein varied between 0.820 and 0.887 for $\mathrm{N}$, and between 0.869 and 0.931 for total AAN. Digestibility of individual amino acids in the original protein was at the same level as for total amino acids, except for cystine which showed a markedly lower digestibility compared to all other amino acids. 
TABLE 2

Degradability of crude protein and amino acids after 4 and $16 \mathrm{~h}$ incubation in the rumen

\begin{tabular}{|c|c|c|c|c|c|c|c|c|}
\hline & \multicolumn{2}{|c|}{ Cocksfoot } & \multicolumn{2}{|c|}{ Vetch whole crop } & \multicolumn{2}{|c|}{ Clover grass } & \multicolumn{2}{|c|}{ Lucerne pellets } \\
\hline & $4 \mathrm{~h}$ & $16 \mathrm{~h}$ & $4 \mathrm{~h}$ & $16 \mathrm{~h}$ & $4 \mathrm{~h}$ & $16 \mathrm{~h}$ & $4 \mathrm{~h}$ & $16 \mathrm{~h}$ \\
\hline Nitrogen crude protein & 0.486 & 0.699 & 0.729 & 0.864 & 0.615 & 0.786 & 0.517 & 0.630 \\
\hline \multicolumn{9}{|l|}{ Amino acid: } \\
\hline Alanine & 0.519 & 0.720 & 0.781 & 0.889 & 0.647 & 0.823 & 0.533 & 0.652 \\
\hline Arginine & 0.428 & 0.677 & 0.714 & 0.875 & 0.617 & 0.810 & 0.489 & 0.633 \\
\hline Aspartic acid & 0.492 & 0.702 & 0.842 & 0.923 & 0.686 & 0.837 & 0.653 & 0.747 \\
\hline Cystine & 0.573 & 0.730 & 0.729 & 0.845 & 0.578 & 0.766 & 0.535 & 0.630 \\
\hline Glutamic acid & 0.499 & 0.708 & 0.717 & 0.871 & 0.618 & 0.819 & 0.514 & 0.660 \\
\hline Glycine & 0.469 & 0.689 & 0.685 & 0.830 & 0.611 & 0.795 & 0.497 & 0.629 \\
\hline Histidine & 0.439 & 0.676 & 0.704 & 0.853 & 0.608 & 0.813 & 0.536 & 0.656 \\
\hline Isoleucine & 0.446 & 0.680 & 0.699 & 0.856 & 0.597 & 0.793 & 0.473 & 0.604 \\
\hline Leucine & 0.432 & 0.672 & 0.684 & 0.861 & 0.587 & 0.793 & 0.474 & 0.619 \\
\hline Lysine & 0.452 & 0.667 & 0.709 & 0.857 & 0.589 & 0.788 & 0.490 & 0.631 \\
\hline Methionine & 0.305 & 0.603 & 0.626 & 0.832 & 0.524 & 0,746 & 0.440 & 0.567 \\
\hline Phenylalanine & 0.462 & 0.671 & 0.678 & 0.871 & 0.587 & 0.802 & 0.460 & 0.642 \\
\hline Proline & 0.471 & 0.696 & 0.715 & 0.861 & 0.681 & 0.841 & 0.535 & 0.652 \\
\hline Serine & 0.472 & 0.685 & 0.728 & 0.870 & 0.611 & 0.796 & 0.498 & 0.642 \\
\hline Threonine & 0.456 & 0.686 & 0.699 & 0.857 & 0.608 & 0.798 & 0.488 & 0.627 \\
\hline Valine & 0.459 & 0.697 & 0.710 & 0.859 & 0.610 & 0.795 & 0.493 & 0.613 \\
\hline Total AAN & 0.460 & 0.686 & 0.728 & 0.871 & 0.618 & 0.807 & 0.516 & 0.648 \\
\hline
\end{tabular}

TABLE 3

The proportion of amino acid nitrogen in total nitrogen before incubation (intact protein) and after 4 and $16 \mathrm{~h}$ incubation in the rumen

\begin{tabular}{lccc}
\hline & Before incubation & $4 \mathrm{~h}$ incubation & $16 \mathrm{~h}$ incubation \\
\hline Cocksfoot & 0.616 & 0.647 & 0.641 \\
Vetch whole crop & 0.604 & 0.606 & 0.573 \\
Clover grass & 0.662 & 0.657 & 0.597 \\
Lucerne pellets & 0.669 & 0.687 & 0.635 \\
\hline
\end{tabular}

The true digestibility of $\mathrm{N}$ and AAN in the undegraded residue after $16 \mathrm{~h}$ of rumen incubation were much lower than values obtained for the original protein. Values for true digestibility of $\mathrm{N}$ varied between 0.444 and 0.748 , and for total AAN between 0.559 and 0.844 . In all feeds the lowest digestibility for an individual amino acid was observed for cystine, and a value as low as 0.294 was found for clover grass. The digestibility of total AAN was higher than for $\mathrm{N}$ in both the intact protein in the different feedstuffs and in the undegraded protein after $16 \mathrm{~h}$ of rumen incubation. 
TABLE 4

Intestinal digestibility of crude protein and amino acids in original protein and undegraded residue after $16 \mathrm{~h}$ of rumen incubation

\begin{tabular}{|c|c|c|c|c|c|c|c|c|}
\hline & \multicolumn{2}{|c|}{ Cocksfoot } & \multicolumn{2}{|c|}{ Vetch whole crop } & \multicolumn{2}{|c|}{ Clover grass } & \multicolumn{2}{|c|}{ Lucerne pellets } \\
\hline & a & b & a & $\mathrm{b}$ & a & $b$ & $\mathbf{a}$ & b \\
\hline Crude protein & 0.820 & 0.696 & 0.872 & 0.444 & 0.865 & 0.567 & 0.887 & 0.748 \\
\hline \multicolumn{9}{|l|}{ Amino acid: } \\
\hline Alanine & 0.880 & 0.772 & 0.912 & 0.477 & 0.904 & 0.637 & 0.931 & 0.834 \\
\hline Arginine & 0.906 & 0.832 & 0.935 & 0.685 & 0.933 & 0.757 & 0.956 & 0.905 \\
\hline Aspartic acid & 0.876 & 0.756 & 0.946 & 0.524 & 0.921 & 0.644 & 0.948 & 0.830 \\
\hline Cystine & 0.778 & 0.499 & 0.829 & 0.332 & 0.756 & 0.294 & 0.868 & 0.731 \\
\hline Glutamic acid & 0.873 & 0.760 & 0.910 & 0.538 & 0.898 & 0.552 & 0.935 & 0.837 \\
\hline Glycine & 0.859 & 0.765 & 0.860 & 0.490 & 0.884 & 0.644 & 0.906 & 0.807 \\
\hline Histidine & 0.858 & 0.764 & 0.884 & 0.551 & 0.895 & 0.655 & 0.919 & 0.828 \\
\hline Isoleucine & 0.865 & 0.787 & 0.907 & 0.608 & 0.896 & 0.662 & 0.926 & 0.859 \\
\hline Leucine & 0.876 & 0.821 & 0.917 & 0.640 & 0.910 & 0.722 & 0.937 & 0.875 \\
\hline Lysine & 0.851 & 0.733 & 0.899 & 0.559 & 0.884 & 0.611 & 0.923 & 0.849 \\
\hline Methionine & 0.819 & 0.772 & 0.878 & 0.526 & 0.865 & 0.620 & 0.924 & 0.852 \\
\hline Phenylalanine & 0.889 & 0.829 & 0.921 & 0.636 & 0.909 & 0.735 & 0.938 & 0.873 \\
\hline Proline & 0.856 & 0.751 & 0.898 & 0.537 & 0.909 & 0.571 & 0.919 & 0.813 \\
\hline Serine & 0.866 & 0.750 & 0.904 & 0.532 & 0.896 & 0.659 & 0.917 & 0.824 \\
\hline Threonine & 0.866 & 0.751 & 0.897 & 0.518 & 0.900 & 0.640 & 0.924 & 0.835 \\
\hline Valine & 0.867 & 0.766 & 0.903 & 0.586 & 0.906 & 0.641 & 0.922 & 0.836 \\
\hline Total AAN & 0.869 & 0.774 & 0.912 & 0.559 & 0.903 & 0.642 & 0.931 & 0.844 \\
\hline
\end{tabular}

$\mathrm{a}=$ original protein

$\mathbf{b}=$ rumen undegraded protein

TABLE 5

The estimated and the calculated true digestibility of crude protein and amino acid nitrogen (AAN) in undegraded protein after $16 \mathrm{~h}$ incubation in the rumen

\begin{tabular}{|c|c|c|c|c|c|c|c|c|}
\hline & \multicolumn{2}{|c|}{ Cocksfoot } & \multicolumn{2}{|c|}{ Vetch whole crop } & \multicolumn{2}{|c|}{ Clover grass } & \multicolumn{2}{|c|}{ Lucerne pellets } \\
\hline & a & b & a & b & $\mathbf{a}$ & $b$ & $\mathbf{a}$ & $b$ \\
\hline Crude protein & 0.696 & 0.402 & 0.444 & 0.059 & 0.567 & 0.369 & 0.748 & 0.694 \\
\hline AAN & 0.774 & 0.583 & 0.559 & 0.318 & 0.642 & 0.497 & 0.844 & 0.804 \\
\hline
\end{tabular}

$\mathrm{a}=$ estimated values

$b=$ calculated values (described in the text)

A comparison of estimated and calculated true digestibility of nitrogen and amino acid nitrogen in the undegraded protein is shown in Table 5.

The true intestinal digestibility of rumen undegraded protein and amino acid nitrogen were calculated according to the following equation for protein 
proposed by Hvelplund et al. (1992) but here also applied for amino acids by substituting protein with amino acids in the equation:

$$
\mathrm{TD}=(\mathrm{UDN}-\mathrm{TU}) / \mathrm{UDN}
$$

where:

TD $=$ true digestibility in the small intestine

$\mathrm{UDN}=$ fraction of undegraded dietary protein (amino acids)

$\mathrm{TU}=$ fraction of true indigestible protein (amino acids) in the feed

The results are shown in Table 5, and considerable differences were observed between the estimated and calculated values according to the above equation. For both $\mathrm{N}$ and AAN a higher true digestibility was obtained by using the mobile nylon bag technique on rumen undegraded protein compared to the calculated value from the equation based on rumen degradation and digestibility of intact protein.

\section{DISCUSSION}

The flow of amino acids to the small intestine in ruminants is not directly related to the amount of amino acids in the feed. The reason for this is degradation of feed protein and microbial protein synthesis in the rumen. These processes can have a substantial effect on the amino acid flow to the intestine compared to the amount found in the feed (Hvelplund and Madsen, 1989). Prediction of the flow of amino acids to the small intestine from undegraded dietary protein is commonly based on degradabilities of crude protein obtained by the nylon bag method. The undegraded dietary protein is then converted to amino acids by a factor representing the proportion of amino acids in the undegraded dietary protein.

In the AAT-PBV protein evaluation system (Madsen, 1985) the factor for the conversion of undegraded dietary protein from roughage to amino acids was estimated to 0.65 . This factor was based on the proportion of amino acids in the protein of roughage rich diets leaving the rumen (Hvelplund and Madsen, 1985), and on estimates of the proportion of amino acids in nylon bag residues after pre-incubation in the rumen (Rooke et al., 1984; Hvelplund, 1987). From these experiments pre-incubation reduced the proportion of amino acids in the undegraded protein compared to the intact feed protein.

The same trend was observed for vetch whole crop, clover grass, and lucerne pellets in this experiment after $16 \mathrm{~h}$ of pre-incubation in the rumen. For cocksfoot the proportion of total amino acids increased due to pre-incubation which indicate a more rapid degradation of those $\mathrm{N}$ containing substances which are not amino acids. For the prediction of intestinal supply of individual amino acids degradation of each single amino acid in the rumen is an important parameter, 
which becomes necessary if the modern protein evaluation systems are extended to include the supply of individual amino acids as well.

Based on an extensive literature review Rulquin and Vérité (1993) concluded that the differences in amino acids profile between feed protein and the corresponding undegraded protein can be considered as rather small, which means that nitrogen degradability can also be used for the individual amino acids. The degradabilities obtained for the different roughages in this study showed some differences between nitrogen degradability and degradability of individual amino acids. Most pronounced, in this respect, was methionine in cocksfoot for which the degradability of this amino acid was 0.18 and 0.10 units lower than for nitrogen after 4 and $16 \mathrm{~h}$ incubation in the rumen.

Not only is the supply of undegraded feed amino acids to the intestine of importance but their subsequent digestion in the intestine is also factor of concern.

The mobile bag technique has been proven to be a reliable and easy technique for the prediction of nitrogen digestibility in concentrates (Hvelplund et al., 1992) but for some roughages, especially of tropical origin containing antinutional factors or highly lignified, recent experiments (Mgheni et al., 1994) have revealed problems with this method as pre-incubation in the rumen influence digestibility of the protein. This means that digestibility of undegraded dietary protein cannot be calculated from information based on the intact protein in some feeds.

Intestinal digestibility of both protein and amino acids in the present experiment were lower for the pre-incubated samples compared to the intact samples, as shown in Table 4. This is in agreement with the concept that proteins contain a fraction which is both undegradable in the rumen and indigestible in the intestine, and lead to a lower digestibility of undegraded protein compared to intact protein, as outlined by Hvelplund et al. (1992).

The hypothesis was tested for both protein and total AAN and substantial deviations were observed between estimated and calculated values (Table 5). The reason for this could possibly be ascribed to the effect of pre-incubation in the rumen, where a part of the indigestible fraction in the intact protein could be degraded by the microbes in the rumen. This has previously been observed for tropical feeds but is obviously also the case for some temperate feeds; however, not for all, as no effect of pre-incubation was found on the amount of indigestible protein for grass silage, rye grass, and clover in an experiment by van Straalen et al. (1993).

For all feeds the digestibility of total AAN was higher than $\mathrm{N}$ digestibility. This is in agreement with earlier observations in which digestibility was estimated in infusion experiments with sheep (Hvelplund, 1985). The reason for this is not clear but may be ascribed to a higher proportion of nitrogen compared to amino acids in the indigestible fraction, which is likely to be cell wall bound protein. 
The lower digestibility of cystine compared to all other amino acids, as shown in Table 4, is in agreement with earlier observations in infusion experiments with sheep (Hvelplund and Hesselholt, 1987), and from studies in which the intestinal disappearance was measured in cannulated animals (Armstrong et al., 1977), and may indicate a low availability of this particular amino acid in a variety of different feeds.

\section{ACKNOWLEDGEMENTS}

The Danish Royal Ministry of Education is gratefully acknowledged for the financial support of Halina Skórko-Sajko's stay in Denmark.

\section{REFERENCES}

A.O.A.C., 1990. Associations of Official Agricultural Chemists. Official Method of Analysis, 15 th Edition. 2200 Wilson Boulevard, Arlington, Virginia 22201, USA

Armstrong D.G., Savage G.P., Harrison D.G., 1977. Digestion of nitrogenous substances entering the small intestine with particular reference to amino acids in ruminant livestock. In: S. Tamminga (Editor), Protein Metabolism and Nurition. Centre for Agricultural Publishing and Documentation. Wageningen, The Netherlands, pp. 55-61

De Boer G., Murphy J.J., Kennelly J.J., 1987. Mobile nylon bag for estimating intestinal availability of rumen undegraded protein. J. Dairy Sci. 70, 977-982

Hvelplund T., 1985. Digestibility of rumen microbial protein and undegraded dietary protein estimated in the small intestine of sheep and by in sacco procedure. Acta Agric. Scand. Suppl. $25,132-144$

Hvelplund T., 1987. Amino acid content of feed and microbial protein and their intestinal digestibility. In: R. Jarrige, G. Alderman (Editors), Feed Evaluation and Protein Requirements Systems for Ruminants. Commission of the EC, pp. 159-169

Hvelplund T., Madsen J., 1985. Amino acid passage to the small intestine in dairy cows compared with estimates of microbial protein and undegraded dietary protein from analysis on the feed. Acta Agric. Scand. Suppl. 25, 21-36

Hvelplund T., Hesselholt M., 1987. Digestibility of individual amino acids in rumen, microbial protein and undegraded dietary protein in the small intestine of sheep. Acta Agric. Scand. 37, 469-477

Hvelplund T., Madsen J., 1989. Prediction of individual amino acid passage to the small intestine of dairy cows from characteristics of the feed. Acta Agric. Scand. 39, 65-78

Hvelplund T., Weisbjerg M.R., Andersen L.S., 1992. Estimation of the true digestibility of rumen undegraded dictary protein in the small intestine of ruminants by the mobile nylon bag technique. Acta Agric. Scand. Sect. A, Anim. Sci. 42, 34-39

Jarosz L., Hvelplund T., Weisbjerg M.R., Jensen B.B., 1994. True digestibility of protein in the small intenstine and the hind gut of cows measured with the mobile bag technique using ${ }^{15} \mathrm{~N}$ labelled roughage. Acta Agric. Scand., Sect. A, Anim. Sci. (in press) 
Kristensen E.S., Møller P.D., Hvelplund T., 1982. Estimation of the effective protein degradability in the rumen of cows using nylon bag technique combined with outflow rate. Acta Agric. Scand. $32,123-127$

Mason V.C., Bech-Andersen S., Rudemo M., 1980. Hydrolisate preparation for amino acid determination in feed constituents. Z. Tierphysiol., Tierernähr. Futtermittelk. 43, 156-164

Madsen J., 1985. The basis for the proposed Nordic protein evaluation system for ruminants. The AAT-PBV system. Acta Agric. Scand. Suppl. 25, 9-20

Madsen J., Hvelplund T., 1994. Prediction of in situ protein degradability in the rumen. Results of an European ringtest. Livest. Prod. Sci. (in press)

Mgheni D.M., Hvelplund T., Weisbjerg M.R., 1994. Intestinal digestibility of rumen undegraded dietary protein of tropical roughages estimated by the mobile nylon bag technique. Acta Agric. Scand.. Sect. A, Anim. Sci. (accepted for publication)

Ørskov E.R., McDonald I., 1979. The estimation of protein degradability in the rumen from incubation measurements weighed according to rate of passage. J. Agric. Sci., Camb. 92, 499-503

Rooke J.A., Greife N.A., Armstrong D.G., 1984. The effect of in saceo rumen incubation of grass silage upon the total and D-amino acid composition of the residual silage dry matter. J.Agric. Sci., Camb. 102, 695-702

Rulquin H., Vérité R., 1993. Amino acid nutrition of dairy cows: Productive effects and animal requirements. In: P.C. Garnsworthy, D.J.A. Cole (Editors), Recent Advances in Animal Nutrition, 1993, Nottingham University Press, pp. 55-77

Van Straalen W.M., Dooper F.M.H., Antoniewicz A.M., Kosmala I., van Vuuren A.M., 1993. Intestinal digestibility in dairy cows of protein from grass and clover measured with mobile nylon bag and other methods. J. Dairy Sci. 76, 2970-2981

\section{STRESZCZENIE}

\section{Rozkład w żwaczu i strawność jelitowa aminokwasów pochodzących z niektórych pasz objętościowych oznaczona metodą woreczków nylonowych}

Oznaczono rozkład białka i poszczególnych aminokwasów w żwaczu po 4 i 16 godz. inkubowaniu w woreczkach nylonowych prób zielonki \% kupkówki, wyki i koniczyny oraz granulowanej lucerny. Strawność jelitową bialka i aminokwasów pasz zwykłych oraz inkubowanych uprzednio w żwaczu przcz 16 godz. oznaczono metodą woreczków mobilnych.

Stwierdzono podobne tendencje w rozkładzie $\mathrm{N}$-aminokwasowego i N-ogólnego w badanych paszach, natomiast znaczne różnice w rozkladzie dotyczyły poszczególnych aminokwasów, szczególnie metioniny.

Strawność jelitowa bialka ogólnego oraz sumy aminokwasów badanych pasz wahala się od 0,820 do 0,887 oraz od 0,869 do 0,931 , odpowiednio. Spośród badanych aminokwasów ubytek cystyny był większy niż pozostałych w porównaniu ze średnią sumy aminokwasów.

Strawność jelitowa białka ogólnego oraz aminokwasów prób inkubowanych uprzednio w żwaczu przez 16 godz. wahala się od 0,444 do 0,748 oraz od 0,559 do 0,844 , odpowiednio. We wszystkich analizowanych próbach strawność $\mathrm{N}$-aminokwasowego była większa niż $\mathrm{N}$-ogólnego. 